\title{
帝京大学病院における人工内耳装用児の実態
}

\begin{abstract}
工藤 多賀 斎藤 宏 小寺一興
要 約：当院で就学前に人工内耳埋め込み術を受け, 術後 2 年以上経過している中途失聴の 小児 7 例に扔いて, 語音聴取能 $(57 \mathrm{~s}$ 語表による語音明瞭度検査) や口話でのコミュニケーショ ン力 (聴覚十読話での WISC-R 知能検査の VIQ) の発達を継時的に観察した. さらに, 人工内 耳装用児の保護者にアンケート調査を行い, 人工内耳装用児の学校生活への適応状況について 検討して, 以下の結果を得た。 1 . 就学時の聴覚認知や聴覚音声でのコミュニケーション力 が不十分な症例は, 学校適応が不良となった. 2 . 術後 2 年以上経過した調查時点においても, 人工内耳装用児の語音明瞭度は補聴器装用の中等度〜高度難聴児の明瞭度に相当していた. 3. 普通学級において, 人工内耳装用児に対する視覚情報を活用した配慮は少なかった。

以上より, 人工内耳装用児に対して, 就学前からの一貫した難聴児教育と治療機関や教育機 関のさらなる連携が必要と考えた。
\end{abstract}

索引用語：中途失聴児, 人工内耳, 聴能発達, コミュニケーション力, 学校適応

\section{Status of Children Who Received Cochlear Implant at Teikyo University School of Medicine}

\author{
Taka Kudo, Hiroshi Saito, Kazuoki Kodera
}

\begin{abstract}
The auditory and communicative abilities of seven schoolchildren were examined before and after cochlear implantation. The subjects were acquired deaf children who received cochlear implants at per-school age. Their communicative abilities were represented by VIQ of the WISC-R as examined employing both auditory and lip-reading delivery. In addition to the above examination, we administered a questionnaire to their parents to learn how matters stand in their children's school life.

The results are summarized as follows.

1. Three children who were poor in auditory or communicative abilities at the time they entered elementary school had difficulty adapting themselves to school life.

2. After more than two years using a cochlear implant, the mean speech perception score of all subjects was similar to that of hearing aid usere with pure-tone average thresholds between 70 and $89 \mathrm{~dB}$, This finding suggests that special education is needed for children with cochlear implants, as it is for severe to profound hearing-impaired children using hearing aids.
\end{abstract}

3 . The children with cochlear implants did not receive education that utilized visual

帝京大学医学部耳鼻咽喉科学教室：干 173-8606 東京都板橋区加賀 2-11-1

Department of Otorhinolaryngology Teikyo University School of Medicine : Kaga, 2-11-1, Itabashi-ku, Tokyo, Japan 1738606

原稿受理：2001 年 4 月 18 日 
media. Teachers did not adequately understand their need for special educational attention. These findings suggest that a multi-disciplinary team approach is needed for rehabilitation of children with cochlear implants.

Key words : acquired deaf children, cochlear implant, development of auditory functions, communicative abilities, adaptation to school life

\section{はじめに}

近年，国内においても人工内耳装用児例が増えてき て, 当院でも就学前に人工内耳埋め込み術を施行した 小児例を 20 例以上経験している．小児例においては， 成人例と異なり, 言語が獲得途上にあるので, 教育環 境の整備が重要である.

人工内耳小児例は言語発達が良好であり"1)，なかで も, 中途失聴児においては, 先天性例に比べて術後の 経過が良(2) といわれている. しかし，一般に，術後の 年単位の聴覚認知や表出語の検查結果だけで経過の良 否が判断されている傾向があり, 各症例の実際のコミ ュニケーションの力や, 実生活への適応状態について の研究は少ない. また, 中途失聴児でも, 失聴年齢や 手術時期, 失聴後の教育の関与によって, その経過は 様々である ${ }^{3,4)}$.

今回，われわれは，2歳から 6 歳までの間に失聴し， 就学前に人工内耳埋め込み術を受けて, 現在は小学校 に通級している人工内耳小児例の聴覚認知と読話を交 えた聴覚音声でのコミュニケーション力の発達経過を 検討した. また, 対象症例の就学時のコミュニケーシ ヨン力と学校適応との関連および, 人工内耳装用児が 学校で置かれている状況を明らかにし，小児人工内耳 例の教育上の問題点を検討したので報告する.

\section{対 象}

対象症例は幼児期に人工内耳埋め込み術を受け, 術 後, 2 年以上経過した中途失聴児 7 例である. 手術時
年齢は 3 歳 0 カ月〜 6 歳 5 カ月で, 今回の調査を行っ た 2000 年 11 月現在の年齢は 7 歳 10 力月〜 9 歳 6 力 月であった。失聴原因は 5 例が髄膜炎， 2 例がムンプ スであった（表 1$)$.

症例の術前の平均聴力 (4 分法による) は全例 130 $\mathrm{dB}$ 以上であった。対象症例の WISC-R 知能検查の PIQ は全例が 90 以上で，正常範囲であった。 また， 失聴前の言語発達は，全例が年齢相当であった。人工 内耳の使用機器はコクレア社ミニシステム 22 , 使用電 極数は 17〜22 本，コード化法はスピーク法であった。 対象症例の就学先は, 全例が普通小学校であった.

\section{方法}

人工内耳装用児が就学した時点での聴覚音声でのコ ミュニケーションカを, 口頭(聴覚十読話)での WISC$\mathrm{R}$ 知能検查で測定した。 WISC $-\mathrm{R}$ 知能検查の VIQ が 良好だった 4 例を就学時コミュニケーション良好群（ 以下, 就学時良好群と略す), 不良だった 3 例を就学時 コミュニケーション不良群 (以下, 就学時不良群と略 す）として分類した。就学時良好群は表 1 の症例 1 $\sim 4$, 就学時不良群は $5 \sim 7$ に該当する. 就学時良好群 と就学時不良群の就学前後の経過を, 定期的に行って いる口頭での WISC- R 知能検査結果, $57 \mathrm{~s}$ 語表での 語音明瞭度検査の結果, 失聴年齢, 手術時期と就学ま での期間, および就学前教育などの観点から検討した。

さらに,「学校への適応抢よび指導内容調査アンケー 卜」を人工内耳装用児の保護者に行い，人工内耳装用 児を取り巻く教育環境について問題点を検討した。

表 1 対象症例の背景

\begin{tabular}{cccrcc}
\hline 症例 & 失聴年齢 & 手術年齢 & 失聴期間 & 失聴原因 & 就学前教育機関 \\
\hline 1 & $4 ; 6$ & $5 ; 6$ & $12 \mathrm{~m}$ & ムンプス & ろう学校 \\
2 & $2 ; 3$ & $3 ; 1$ & $10 \mathrm{~m}$ & 髄膜炎 & ろう学校 \\
3 & $2 ; 6$ & $4 ; 2$ & $1 \mathrm{y} 8 \mathrm{~m}$ & 䯋膜炎 & クリニック \\
4 & $2 ; 2$ & $3 ; 0$ & $10 \mathrm{~m}$ & 髄膜炎 & ろう学校 \\
5 & $6 ; 2$ & $6 ; 5$ & $3 \mathrm{~m}$ & ムンプス & クリニック \\
6 & $4 ; 7$ & $5 ; 10$ & $1 \mathrm{y} 3 \mathrm{~m}$ & 髄膜炎 & 通園施設 \\
7 & $5 ; 0$ & $6 ; 1$ & $1 \mathrm{y} 1 \mathrm{~m}$ & 髄膜炎 & 通園施設 \\
\hline
\end{tabular}




\section{結 果}

\section{1.コミュニケーションカの発達}

図 1 に今回対象とした人工内耳装用児 7 名の WISC-R 知能検查の VIQ の発達経過を就学時期との 関連で示した.この検査は口頭で行っているので，こ の結果を読話を交えた聴覚音声でのコミュニケーショ ン力と解釈した。

就学時の VIQ が 75 以上の就学時良好群 4 例のう ち, 3 例は手術から就学までの期間が長く, 術後 33 力 月以上であって, 就学時にはVIQ が 100 前後と健聴児 の平均に達していた。症例 1 は就学までの期間が短く, 症例 2 , 症例 3 , 症例 4 に比べて, 就学時のコミュニケ 一ション力は低かったが, 就学後, 徐々に発達し, 術 後 2 年半の時点でVIQ は 89 であった。

一方, 就学時の VIQ が 45 以下と測定不能であった 就学時不良群はいずれも手術から就学までの期間は 13 力月以下と短かった. 不良群のうち, 症例 5 は術後, 急激な発達がみられたが, 症例 6 と症例 7 は術後の発 達が遅く, 症例 6 は術後 3 年を経て VIQ が 78, 症例 7 は 2 年を経て 50 であった。

\section{2. 聴取能の発達}

図 2 に人工内耳装用児の聴取能の発達経過を示し た. 4 歳以上で失聴した症例 1 , 症例 5 , 症例 6 は急激 な発達過程をたどり，術後 12 力月前後で，いずれも語 音明瞭度が $60 \%$ 以上とほぼプラトーに達していた。症 例 7 は 4 歳以上で失聴したにもかかわらず，聴取能の 発達が遅れていた。失聴年噛が低く, 2 歳代だった症 例 2 , 症例 3, 症例 4 はゆるやかな発達過程をたどり,
術後 2 年以上たってからプラトーに達した。

また，就学した時点での聴取能を良好群と不良群で 比較すると, 就学時良好群では全例が, 就学したとき の明瞭度が $60 \%$ 以上と良好であった。一方，不良群 では, 手術から就学までの期間が 12 力月未満と短かっ た 2 例が $20 \%$ 末満と低く,術後 1 年 1 力月で就学した 症例 6 のみが $70 \%$ を超えていた。

\section{3. 就学前教育について}

就学前教育機関は失聴年齢が低い症例ではろう学 校，失聴年齢が高い症例はクリニックないし，通園施 設を選択している傾向がみられた。しかし，4歳代で失 聴した症例 1 と症例 6 では就学前教育機関が一方がろ う学校，一方が通園施設と異なっていた（表 1 ）。

\section{4. 学校生活について}

人工内耳装用児の保護者に対して行ったアンケート 結果を図 3 , 図 4 , 図 5 , 図 6 に示した。学校適応全 般に関しては, 就学時不良群において,「授業について いけない」という訴えが 3 人中 3 人に，「登校したがら ない」が 2 人に，「友人関係のトラブルが多い」が 1 人 にみられた(図 3 )。一方, 就学時良好群では, そのよ うな問題はみられなかった。

図 4 に人工内耳装用児に対する学級担任の配慮の状 況を示した。「席の位置」「FMシステムの活用」な どの配慮は良好群，不良群を含めた 7 例中 6 例とほほ 全例になされていた。「はっきり話す」は 1 例，「板 書を増やす」は 2 例いずれも良好群のみに行われてい た。事前に「プリントを配る」ことは全くされていな かった。

図 5 に人工内耳装用児が通級している難聴学級の指
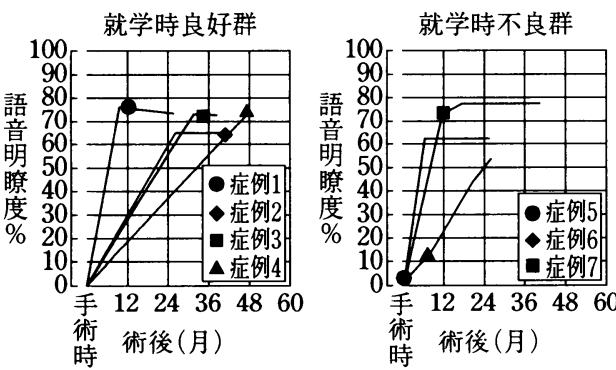

図 2 聴取能の発達経過. 7 症例について, $57 \mathrm{~s}$ 語表 で行った語音明瞭度検査の発達経過を就学時 良好群と不良群に分けて示す．検査は音源か ら $1 \mathrm{~m}$ の距離，入力 $70 \mathrm{dBSPL}$ で行った. 横 軸は術後の月数を示す．○ロムは各症例の 就学時期 (手術から就学までの期間) と就学時 の語音明瞭度を示す 


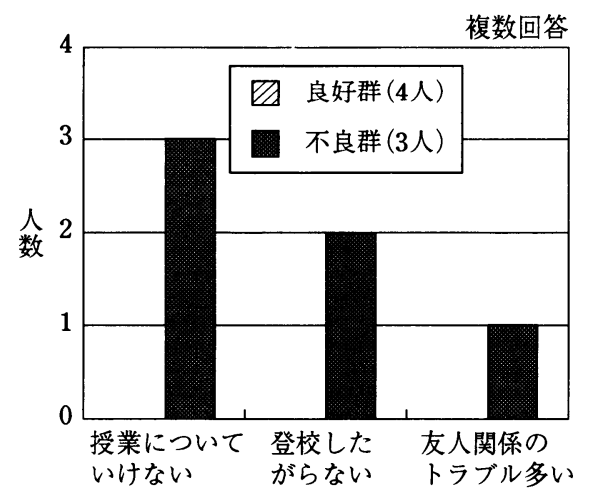

図 3 人工内耳装用児アンケート結果＜学校での問 題 $>$. 人工内耳装用児 7 名の保護者に対して 行ったアンケート結果. 各項目の該当者数を 示した. 囚は就学時良好群, 固は就学時不良群 を示す

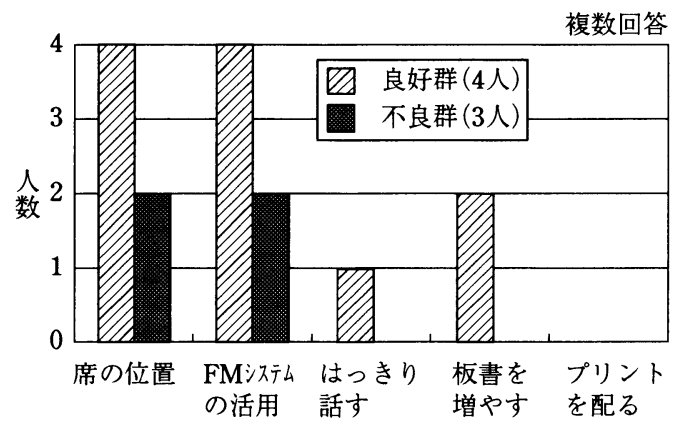

図4人工内耳装用児アンケート結果 $<$ 学級担任の 授業への配慮 $>$. 囚は就学時良好群, 回は就学 時不良群を示す

導内容を示した。良好群, 不良群を含めると,「授業 の補習」が 5 例と最も多くされていた。「ことばの指 導」は, 良好群では 4 例全例が受けていたが, 不良群 では，受けている症例はなかった。

図 6 に, 人工内耳装用児の友達とのコミュニケーシ ヨンの状況を示した. 友達とのコミュニケーションは 1 対 1 の対話においては，全例が「不自由なし」との ことだったが,多人数の中でのコミュニケーションは, 「不自由なし」が 1 例のみで, 7 例中 6 例に「簡単な会 話のみ可能」との回答を得た。

\section{考察}

今回の症例の保護者に対して行ったアンケートか ら, 就学後の学校適応に問題がみられたのは, 就学時 の聴覚口話でのコミュニケーションが不良な群におい てであった(図 3 )。このことから, 人工内耳装用児の

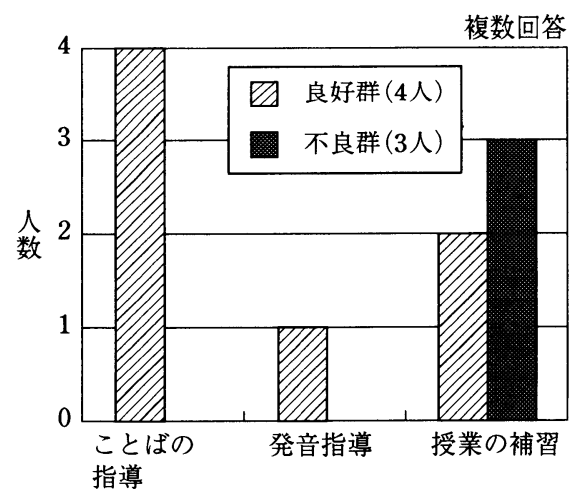

図 5 人工内耳装用児アンケート結果 $<$ 難聴学級の 指導内容 $>$. 囚は就学時良好群, 回は就学時不 良群を示す
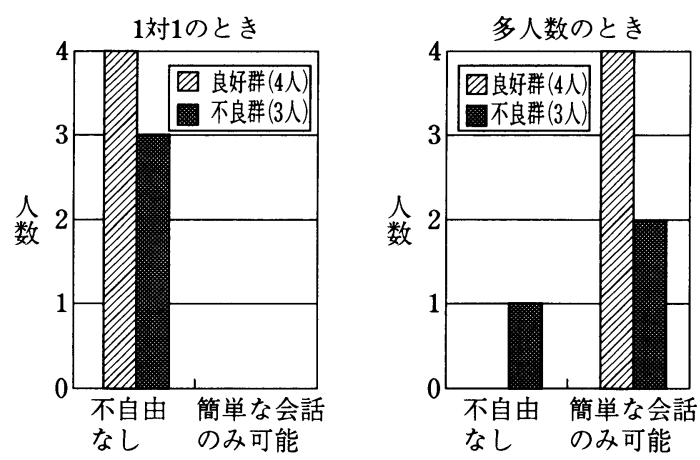

図 6 人工内耳装用児アンケート結果<友達とのコ ミュニケーション>. 友達とのコミュニケー ションの状況について, 1 対 1 の時と多人数の 中での時に分けて示した. 凤は就学時良好群,

四は就学時不良群を示す

学校適応に関して, 就学時の聴覚音声でのコミュニケ ーション力が決定的な要因であると考えられる.

良好群において就学時のコミュニケーション力が良 好だった要因としては, 症例 2 , 症例 3 , 症例 4 は失 聴年齢が低く, 手術から就学までの期間が平均 40 力月 と長かったため, 聴取能が発達したことが大きい.

一方, 就学時不良群では, 失聴年齢が高かったため, 手術から就学までの期間が短かった. 就学時の聴取能 は, 手術後 13 力月を経過していた症例 6 のみが $70 \%$ を超えていたが, 就学時が術後 1 年末満の症例 5 と症 例 7 は $20 \%$ 未満であった。

今回, 聴取能において急激な発達を示したのは, 症 例 1 （失聴年齢は $4 ； 6$ ） と症例 5 (失聴年齢は $6 ; 2$ ), 
症例 6 (失聴年齢は $4 ; 7$ ) であり,術後 7 カ月から 18 力 月にかけてプラトーに達していた。失聴年齢が低かっ た症例 2 , 症例 3 , 症例 4 は聴取能の発達において, Fryauf-Bertschy ら ${ }^{5)}$ にって報告された先天性症例 と同様な緩慢な発達経過を示し, プラトーに達するの に 2 年から 3 年以上を要している.また, 症例 7 のよ うに失聴年齢が高くても発達がゆっくりなケースがみ られた。これらのことは，中途失聴児でも，聴取能が 十分発達するには, 早くて半年以上, 遅い場合には 3 年くらい要する症例があることを示している.

中途失聴の人工内耳装用児のコミュニケーションに 関して, 内藤ら ${ }^{6}$ は言語習得中失聴児の中で, 音声言語 によるコミュニケーションが，術後早期に失聴前のレ ベルに達した例と，言語習得前失聴児同様のゆるやか な発達をした例がいたと報告している。

今回の調查で, 症例 5 と症例 7 の就学時のコミュニ ケーション力の低さは主に聴取能の低さに由来してい ると考えられる.しかし, 症例 6 については, 就学時 点での語音明瞭度が $72 \%$ と良好であったのに拘らず, コミュニケーションカは聴覚音声での VIQ が 45 以下 と低いレベルにとどまっていた。このことは聴取能が 良好であればコミュニケーション力も良好であるとは いえないことを示している.

失聴年齢と手術年齢がほほ同じ症例 1 と症例 6 の経 過を比較してみると, 症例 1 では, 失聴年齢が高く, 失聴前の言語発達が正常であったにも拘らず, 親が危 機感を抱いて, 失聴直後から小学校入学まで 1 年半に わたってろう学校での教育を受けていた.この結果, 難聴児としての聴覚音声でのコミュニケーション手段 が確実なものになり, 言語発達およびコミュニケーシ ヨン力が保証されたと考えられる。これに対し, 症例 6 は, 主に通園施設で教育を受けていたが, 家からの距 離的な問題もあって, 指導日数は 週 1 回程度と十分で はなかった。 Robbins ら〕は, 中途失聴の人工内耳装用 児の言語発達を, 人工内耳にしなかった場合の発達予 測と比較した。その結果，人工内耳装用児の方が発達 が良好であるが，それは，年齢相当に発達するという ことではない，と指摘している。つまり，中途失聴の 人工内耳装用児であっても, 言語獲得促進のためには, 時間をかけた適切な教育が必要である。

図 7 に当院で幼少時から指導を受けた難聴児 28 名 の就学時の語音明瞭度と, 今回対象とした人工内耳装 用児の語音明瞭度を比較して示した．就学時不良群に おいても術後 2 年以上経た調查時現在, 聴取能の改善 がみられた。しかし, 調查時においても, 明瞭度は良 好群が平均 $72 \%$, 不良群が $64 \%$ あっって, 補聴器装
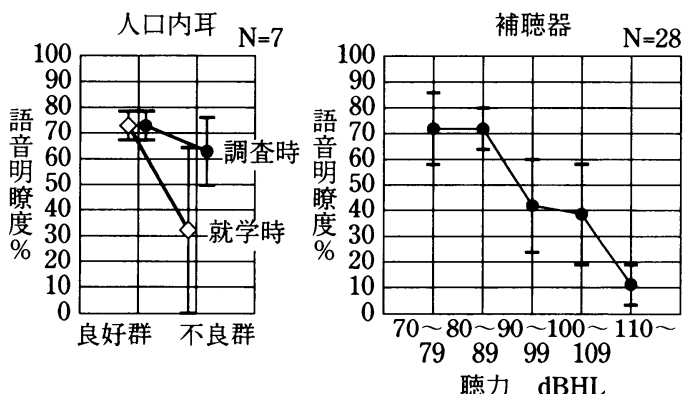

図 7 人工内耳装用児と補聴器装用児の語音明瞭 度. 人工内耳装用児と補聴器装用児の語音明 瞭度の平均値を示した. 補聴器装用児の明瞭 度は聴力別に示した. $70 \sim 79 \mathrm{~dB}$ 群は 5 名, $80 \sim 89 \mathrm{~dB}$ 群は 5 名, $90 \sim 99 \mathrm{~dB}$ 群は 8 名, $100 \sim 109 \mathrm{~dB}$ 群は 6 名, $110 \mathrm{~dB}$ 以上群は 4 名 であった. 人工内耳症例において，〉は良好 群, 不良群とも, 就学時の語音明瞭度, は良 好群, 不良群とも調查時の明瞭度を示す。縦の バーは土1 SDを示す

用の難聴児の $70 \sim 89 \mathrm{~dB}$ 群，いわゆる中等度から高度 難聴群に相当していた。長谷川 ${ }^{87}$ や山山ら ${ }^{9}$ は軽・中等 度難聴であっても, 平均聴力レベルが $40 \mathrm{~dB}$ 以上にな ると言語発達が遅れると報告している. 以上のことか ら，人工内耳装用児であっても，難聴児としての教育 は不可欠であると考えられる ${ }^{10)}$.

河野 ${ }^{4}$ は幼小児の人工内耳について考えるべき問題 のひとつとして人工内耳を埋め込むと, 即言語獲得が できると考えている養育者がいることをあげている. 今回の調査で，低年齢で失聴した子が多い就学時良好 群は, 失聴後の言語発達を危惧して保護者が難聴児教 育に積極的に取り組む傾向がみられた。一方, 就学時 不良群では，比較的高い年齢で失聴していて，失聴前 には日常会話には支障がなかったため, 保護者は聴力 が元に戻ることのみを考える傾向があり，難聴児教育 に消極的であった．養育者の姿勢の違いが就学時良好 群と不良群に分かれた要因の一つとも考えられる。川 野ら ${ }^{11)}$ も途失聴の人工内耳装用児の保護者が難聴の 障害受容をすることの難しさを指摘している。このよ うな保護者に対して，人工内耳装用児の実態を正しく 把握してもらい，難聴児教育の必要性について適切な 助言をしていくのも，人工内耳の医療と教育に携わっ ている者の責務であると考えた。

学校教育においては, 普通学級に在籍する難聴児に 対して, 担任教師は様々な配慮をしている ${ }^{12,13)}$. 伊東 $ら^{12}$ は，普通学級に在籍する難聴の高校生に対する調 
査から, 授業内容の理解において, 有意な関連性があ ったものとして,「板書」, および「読話」つまり口型 をみせてはっきり話すことをあげている．武田 ${ }^{13)}$ が難 聴児を担任している通常学級の担任に対して行った調 査では, 教師が実際行っている配慮は, 「口型をみせて はっきり話す」が $33.3 \%$ と最も多く，「板書をよくす る」が $10.9 \%$ と, 視覚的手段が多く用いられていた。 武田の調査では, 聴力レベルが $90 \mathrm{~dB}$ 以上の高度難聴 児が $73 \%$ \%゙った。高度難聴の症例が多かったため, 聴覚障害の状況が教師にも把握されやすく, 適切な配 慮がなされたと考えられる.一方，今回対象とした人 工内耳装用児の保護者へのアンケート結果から，学級 担任の授業への配慮では,「席の位置」「F M システム の活用」といった聴覚補障に類する配慮は就学時良好 群, 不良群ともに対してなされていた。しかし,「口型 をみせてはっきり話す」「板書を增やす」「プリントを 増やす」といった視覚的なコミュニケーション手段は あまり使われていなかった。

補聴器装用児は, 軽・中等度難聴であっても, 学校

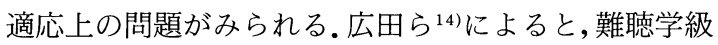
担任へのアンケートで, 学校適応に問題があるか, や や問題がある難聴児の聴力は, 70 $99 \mathrm{~dB}$ 群が $40 \%$ あ り, $70 \mathrm{~dB}$ 未満でも $20 \%$ を超えていた. 同じく広田 ら ${ }^{14)}$ は学校適応上の問題点として,「授業についていけ ない」が最も多く, 次に「コミュニケーションが正確 に取れない」をあげている。

今回対象とした人工内耳装用児は, 聴取能の成績か ら, 語音の聴取に関して, 補聴器装用の中〜高度難聴 児に相当する. しかし，一般に，人工内耳装用児は， 高度難聴児に比べて, 聴覚的反応が良く, 難聴児とし ての問題が，見過ごされやすい傾向がある. 今回の調 查でも, 通常学級に扔いては, 人工内耳装用児に対す る教育的な理解や配慮が少ないと考えられた。

人工内耳装用児が通級している難聴学級の指導内容 は, 就学時良好群, 就学時不良群を含めると, 「授業の 補習」が最も多くされていた。 しかし, 就学時不良群 に対して行われているのは授業の補習のみで, 良好群 に対して行われているような「ことばの指導」や「発 音指導」は全くなされていなかった。就学時不良群は 聴覚音声でのコミュニケーション力が, 就学した時も, 調查時点においても,十分でないので,「ことばの指導」 は就学後も必須であると考えた。このようなことから も, 人工内耳装用児を直接指導している難聴学級の教 師も人工内耳装用児の状況を正しく認識しているとは いえない様子がうかがえた。

学習以外の面では, 人工内耳装用児は, 多人数の中
での友達とのコミュニケーションに困難を感じてい た。広田ら $\left.{ }^{14}\right)$ は軽・中等度難聴児において「友人関係が 親密でない」「自分勝手な行動をとる」など適応上の問 題点を指摘している.このような問題点が, 人工内耳 装用児においても，コミュニケーションの困難さから 生じてくる可能性は大きい.このような学校生活全般 の問題に対して, 将来にわたって, 適切に対応してい くために, 医療機関と就学前教育機関, 就学後教育機 関, そして, 保護者の連携の必要性を痛感した。

\section{ま と め}

当院において人工内耳手術を施行した後天性難聴小 坚 7 例（就学時良好群 4 例，就学時不良群 3 例）につ いて, 聴覚認知や聴覚音声でのコミュニケーション力 の発達を継時的に観察して, その実態を明らかにした。 さらに, 人工内耳装用児の保護者に対して，「学校への 適応および指導内容調查アンケート」を行い，人工内 耳装用児のおかれている状況を明らかにして, 教育上 の問題点を検討した結果, 以下の結論を得た.

1. 就学時の聴覚認知や聴覚音声でのコミュニケー ション力が不十分な症例は, 学校適応が不良となった。

2. 中途失聴の人工内耳装用児に対しても, 中等度 〜高度難聴の補聴器装用児に対するのと同様に, 就学 前からの一貫した難聴児教育が必要と考えられた。

3.人工内耳装用児は, 学校教育においては十分配 慮されているとはいえず, 就学前の治療教育機関と普 通学級, 難聴学級, そして, 保護者のさらなる連携が 必要と考えた。

\section{文献}

1）設楽仁一, 小寺一興, 斎藤 宏, 他: 小児人工内耳 4 症例の聴覚・言語発達. Audiology Japan, 41： 182-187, 1998.

2) Gantz, B. J., Tyler, R. S., Woodworth, G. G., et al.: Results of multichannel cochlear implants in congenital and acquired prelingual deafness in children : Five-year follow-up. Am J Otol, 15 : 1-7, 1994.

3）内藤 泰, 藤木暢也, 森田武志, 他: 小児人工内 耳の適応とリハビリテーション. Otol Jpn, $9: 97$ $-103,1999$.

4）河野淳, 間三千夫：幼小児の人工内耳. JOHNS, $16: 227-231,2000$.

5) Fryauf-Bertschy, H., Tyler, R. S., Kelsey, D. M., et al. : Performance over time of congenitally deaf and postlingually deafened children using 
a multichannel cochlear implant. J Speech Hear Res, 35 : 913-920, 1992.

6）内藤 泰, 森田武志，山口 忍，他：小児人工内 耳例の長期経過. Audiology Japan, $43 ： 121-122$, 2000.

7) Robbins, A. M., Osberger, M. J., Miyamoto, R. $\mathrm{T}$., et al. : Language development in young children with cochlear implant. Adv Otorhinolaryngol, $50: 160-166,1994$.

8）長谷川寿珠：軽・中等度両側感音難聴児の聴力と 言語に関する研究. 日耳鼻, $93 ： 1397-1409,1990$.

9）中山博之，荒尾はるみ，幸田政次，他：軽・中等 度感音難聴児の言語および構音の発達 $-0.5 ・ 1 ・$ $2 \cdot 4 \mathrm{kHz}$ との関係について-. Audiology Japan, $39: 45-54,1996$.

10）田中美郷，小寺一興，北 義子, 他：人工内耳を 装着した先天性重度感音難聴幼児 2 例の聴能・言 語発達経過. 音声言語医学, 40：329-341， 1999.
11）川野通夫, 本庄 樷, 内藤 泰, 他：人工内耳装 着学童への援助. 音声言語医学, $37: 378-382$, 1996.

12）伊東靖雄，四日市章：通常の学級における聴覚障 害高校生の学習環境. 聴覚言語障害, 28：151-162, 1999.

13）武田 修：小学校における聴覚障害児の学校適応 状況について一調査報告一. 万う教育科学, 33 ： 45-71，1991.

14）広田栄子，芦野聡子，田中美郷，他：聴覚障害児 の学校適応についての実態調査. 昭和 62 年度厚生 省心身障害研究。心身障害児療育技術の開発に関 する研究「難聴と言語障害（田中美郷班）」ワーク ショップ記録：38-43，1988。

別刷請求先： $\bar{\top}$ 173-8606 東京都板橋区加賀 2-11-1 帝京大学医学部耳鼻咽喉科学教室 工藤多賀 